\title{
TEKNIK PEMBENIHAN IKAN GURAME (Osphronemus gouramy) DI BALAI BENIH IKAN NGORO, JOMBANG
}

\section{Gouramy (Osphronemus gouramy) Breeding Techniques at Fish Seed Center Ngoro, Jombang}

\author{
Budiana $^{1 *}$ and Boedi Setya Rahardja ${ }^{2}$. \\ ${ }^{1}$ Program Studi Budidaya Perairan, Fakultas Perikanan dan Kelautan, Universitas Airlangga, Surabaya \\ ${ }^{2}$ Departemen Manajemen Kesehatan Ikan dan Budidaya Perairan, Fakultas Perikanan dan Kelautan, Universitas \\ Airlangga, Surabaya \\ *budiana-2015@fpk.unair.ac.id
}

\begin{abstract}
Abstrak
Indonesia memiliki potensi lahan budidaya yang cukup besar untuk mengembangkan budidaya ikan, salah satunya adalah ikan gurame. Ikan gurame merupakan ikan air tawar asli Indonesia yang termasuk dalam famili Labyrinthici. Ikan gurame sudah lama dibudidayakan dan dikonsumsi masyarakat karena rasa dagingnya lezat dan memiliki nilai ekonomis tinggi. Pembenihan ikan gurame memiliki potensi tinggi untuk dilakukan karena produksi ikan gurame dari tahun ke tahun cenderung meningkat sehingga tingkat permintaan benih ikan gurame juga mengalami peningkatan.

Praktek Kerja Lapang (PKL) dilaksanakan di Balai Benih Ikan Ngoro, Jombang pada tanggal 19 Desember 2017 sampai 19 Januari 2018. Tujuan Praktek Kerja Lapang ini adalah untuk mengetahui teknik pembenihan ikan gurame (Osphronemus gouramy) dan hambatan yang dihadapi dalam teknik pembenihan ikan gurame (Osphronemus gouramy). Metode kerja yang digunakan adalah metode partisipasi aktif dengan pengumpulan data meliputi data primer berupa observasi, wawancara dan partisipasi aktif serta data sekunder berupa studi pustaka untuk melengkapi data yang dikumpulkan.

Teknik pembenihan ikan gurame (Osphronemus gouramy) di Balai Benih Ikan Ngoro, Jombang meliputi tahap persiapan kolam pemijahan, seleksi induk, pemijahan, pemanenan telur, penetasan telur dan pemeliharaan larva, pendederan, hama dan penyakit, panen dan pasca panen. Pemijahan dilakukan di kolam beton dengan perbandingan induk jantan dan betina 1:2. Nilai FR (Fertilization Rate), HR (Hatching Rate) dan SR (Survival Rate) yang didapatkan secara berturut-turut adalah 53,54 \%; 87,73 \% dan 86,26 \%. Hambatan yang terdapat dalam teknik pembenihan ikan gurame (Osphronemus gouramy) di Balai Benih Ikan Ngoro, Jombang terdiri atas faktor internal yaitu biologis ikan dan faktor eksternal yaitu faktor lingkungan, kualitas air dan penyakit.
\end{abstract}

Kata kunci: Balai Benih Ikan Ngoro Jombang, Ikan Gurame dan Teknik Pembenihan

\begin{abstract}
Indonesia has a large enough cultivation potential to develop fish cultivation, one of them is gouramy. Gouramy is a native Indonesian freshwater fish belonging to the Labyrinthici family. Gouramy has been long cultivated and consumed by the society because the taste of its meat is delicious and has high economic value. Gouramy breeding has a high potential to be done because the production of gouramy from year to year tends to increase so that the request of gouramy fish seeds are also increased.

Field Work Practice was carried out at fish seed center Ngoro, Jombang on 19 December 2017 until 19 January 2018. The aim of this Field Work Practice is to know gouramy (Osphronemus gouramy) breeding techniques and the obstacles faced in the gouramy (Osphronemus gouramy) breeding techniques. Working method used during Field Work Practice was active participation with data collection were primary data include observation, interview and active participation as well as secondary data include literature study to complete the data collected.

Gouramy (Osphronemus gouramy) breeding techniques at fish seed center Ngoro, Jombang were included the preparation stage of spawning pond, parent selection, spawning, egg harvesting, egg hatching and larval maintenance, nursery, pests and diseases, harvest and post harvest. Spawning has been carried out in concrete ponds with a ratio of male and female broodstock 1: 2. The values of FR (Fertilization Rate), HR (Hatching Rate) and SR (Survival Rate) obtained respectively are 53.54\%; 87.73\% and 86.26\%. The obstacles
\end{abstract}


in gouramy (Osphronemus gouramy) breeding techniques at fish seed center Ngoro, Jombang consists of internal factors of biological fish and external factors such as environmental factors, water quality and disease.

Keywords: Breeding Technique, Fish Seed Center Ngoro Jombang and Gouramy

\section{PENDAHULUAN}

Indonesia merupakan negara yang memiliki potensi perikanan sangat besar karena hampir sebagian besar wilayah Indonesia terdiri atas perairan sungai, rawa, danau, telaga, sawah, tambak dan laut. Usaha budidaya ikan dapat dilakukan di tambak, kolam, karamba dan jaring apung. Tingkatan teknologi yang diterapkan untuk budidaya dapat dilakukan secara intensif, semi intensif dan tradisional. Budidaya ikan yang dikembangkan misalnya ikan gurame, ikan mas, ikan lele, ikan nila, ikan patin dan ikan bandeng (Irawan dkk., 2012).

Ikan gurame (Osphronemus gouramy) merupakan salah satu jenis ikan air tawar asli Indonesia yang sudah lama dibudidayakan dan dikonsumsi masyarakat karena rasa dagingnya yang lezat, sehingga memiliki nilai ekonomis yang tinggi. Subsistem pembenihan ikan gurame meliputi kegiatan pemeliharaan induk, pemijahan, penetasan telur dan perawatan larva hingga menghasilkan benih (Khairuman dan Khairul, 2005).

Tingkat permintaan benih ikan gurame dari tahun 2000-2004 mengalami peningkatan, dengan peningkatan rata-rata pertahun sebesar 42,25\% (Ditjen Perikanan Budidaya, 2007 dalam Nugroho, 2008). Peningkatan permintaan benih ikan gurame ini menunjukkan bahwa usaha pembenihan ikan gurame sangat menjanjikan, namun permasalahan dalam pembenihan juga dapat timbul seperti tingginya tingkat kematian, rendahnya fekunditas telur, rendahnya derajat pembuahan dan penetasan telur, serta beragamnya ukuran benih pada pemeliharaan di kolam (Nugroho, 2008). Selain itu, benih gurame yang berasal dari hasil pemijahan alami yang dipengaruhi oleh musim merupakan suatu kesulitan tersendiri karena ketersediaannya yang tidak kontinyu dan masih sangat terbatas (Arfah dkk., 2006). Oleh karena itu, diperlukan pelaksanaan praktek kerja lapang tentang teknik pembenihan ikan gurame (Osphronemus gouramy) di Balai Benih Ikan Ngoro, Jombang.

Tujuan dari Praktek Kerja Lapang ini adalah mengetahui teknik pembenihan ikan gurame (Osphronemus gouramy) dan hambatan dalam pembenihan ikan gurame (Osphronemus gouramy) secara langsung di Balai Benih Ikan Ngoro, Jombang.

Manfaat yang diberikan antara lain mendapatkan pengetahuan mengenai teknik pembenihan ikan gurame (Osphronemus gouramy) dan hambatan dalam pembenihan ikan gurame (Osphronemus gouramy) secara langsung di Balai Benih Ikan Ngoro, Jombang.

\section{METODOLOGI \\ Waktu dan Tempat}

Praktek Kerja Lapang ini dilaksanakan di Balai Benih Ikan Ngoro, Jombang. Kegiatan Praktek Kerja Lapang dilaksanakan pada tanggal 19 Desember 2017 sampai dengan 19 Januari 2018.

\section{Metode Penelitian}

Metode kerja yang digunakan adalah metode partisipasi aktif dengan pengumpulan data meliputi data primer berupa observasi, wawancara dan partisipasi aktif serta data sekunder berupa studi pustaka untuk melengkapi data yang dikumpulkan.

\section{HASIL DAN PEMBAHASAN \\ Teknik Pembenihan Ikan Gurame Persiapan Kolam Pemijahan}

Pemijahan ikan gurame dilakukan di kolam beton berbentuk persegi panjang dengan ukuran 19,3 m x 6,3 m x $1 \mathrm{~m}$. Pemijahan gurame menggunakan kolam beton bertujuan untuk mengurangi 
serangan hama yang biasanya sering muncul di kolam tanah (Satyani dan Bambang, 2012). Kolam pemijahan dipersiapkan terlebih dahulu sebelum digunakan. Persiapan yang dilakukan meliputi pembersihan kolam dan pematang kolam agar tidak dijadikan tempat persembunyian hama, pengeringan kolam selama dua sampai tiga hari untuk membunuh hama dan penyakit yang berada pada kolam, pengisian air kolam sampai ketinggian air mencapai $80-90 \mathrm{~cm}$ karena habitat alami ikan gurame adalah di rawa dan menyukai air tenang (Sulhi,
2010), pemasangan sarang apung yang terbuat dari rangkaian paralon kemudian dipasangi sosok dan peletakkan bahan pembentuk sarang berupa cacahan karung pada para-para kawat.

\section{Seleksi Induk}

Seleksi induk dilakukan untuk mendapatkan induk yang baik dan matang gonad. Menurut Fais (2008) ciri-ciri induk gurame jantan dan betina yang matang gonad dapat dilihat pada Tabel 1.

Tabel 1. Ciri-ciri induk gurame jantan dan betina yang matang gonad

\begin{tabular}{ccc}
\hline Ciri Fisik & Induk Jantan & Induk Betina \\
\hline Wama & Hitam & Relatif terang \\
Perut & Membentuk sudut tumpul & Membulat \\
Susunan sisik & Normal & Sedikit terbuka \\
Gerakan & Lincah & Lamban \\
Perut distriping & Mengeluarkan cairan sperma & Tidak mengeluarkan cairan \\
\hline
\end{tabular}

Sumber: Fais (2008)

Tabel 2. Perbedaan ikan gurame jantan dan betina

\begin{tabular}{cc}
\hline Jantan & Betina \\
\hline Memiliki tonjolan jelas di dahi & Tidak memiliki tonjolan jelas di dahi \\
Sirip ekor rata & Sirip ekor membulat \\
Bibir tebal & Bibir tipis \\
Gerak lincah & Gerak lamban \\
Bentuk tubuh atau perut langsing & Bentuk tubuh atau perut gendut \\
Jika diletakkan di tempat datar & Ekor hanya bergerak-gerak \\
ekor akan naik & \\
\hline Sumber: Sulhi (2010) &
\end{tabular}

Tabel 3. Persyaratan khusus induk gurame untuk pembenihan

\begin{tabular}{cc}
\hline Jantan & Betina \\
\hline Berat 2-2,5 kg/ekor & Berat 2,5-3 kg/ekor \\
Umur minimal 2 tahun & Umur minimal 2 tahun \\
Tonjolan pada kelamin terlihat jelas & Perut membulat \\
Kekar dan lincah & Alat kelamin kemerahan \\
\hline
\end{tabular}

Sumber: Sulhi (2010)

Induk gurame jantan memiliki ciri tubuh dahi menonjol, pangkal sirip dada berwarna keputihan dan perut langsing.
Induk gurame betina memiliki ciri tubuh tidak memiliki tonjolan pada dahi, pangkal sirip dada berwarna gelap kehitaman dan 
perut agak lunak bila diraba. Hal tersebut sesuai dengan pendapat Sulhi (2010) mengenai perbedaan induk gurame jantan dan betina dapat dilihat pada Tabel 2 .

Indukan yang digunakan dalam pemijahan di Balai Benih Ikan Ngoro berumur empat tahun dengan berat badan $2 \mathrm{~kg}$ untuk induk gurame jantan dan 2,5 kg untuk induk gurame betina. Menurut Sulhi (2010) persyaratan khusus induk gurame untuk pembenihan dapat dilihat pada Tabel 3.

\section{Pemijahan}

Pemijahan gurame dilakukan secara alami dengan sistem massal. Perbandingan induk jantan dan betina adalah $1: 2$ dengan 50 ekor induk gurame jantan dan 100 ekor induk gurame betina. Perbandingan ini bertujuan agar pemijahan yang dilakukan lebih efektif karena hampir semua sel ovum dapat dibuahi oleh sel sperma (Mukti, 2005 dalam Caniago dkk., 2014).

Indukan gurame di kolam pemijahan diberi pakan daun talas dengan frekuensi dua hari sekali secara ad-libitum. Daun talas digunakan sebagai pakan induk ikan gurame karena mengandung 32 \% protein yang berguna untuk pematangan gonad induk. Selain itu, daun talas mengandung vitamin $\mathrm{C}$, flavonoid dan polifenol pada tangkai dan daun yang dapat meningkatkan daya tahan ikan terhadap serangan penyakit, rimpangnya kaya akan pati dan daunnya dapat digunakan untuk meningkatkan fertilitas (Sulhi dkk., 2012). Pemberian pakan dengan kadar protein tinggi dapat memacu perkembangan gonad dan mendorong terjadinya pemijahan (Gunadi dkk., 2010).

\section{Pemanenan Telur}

Pemanenan telur dilakukan dengan pemeriksaan sarang terlebih dahulu. Menurut Sulhi (2010), ciri sarang berisi telur adalah terdapat lapisan minyak di atas permukaan air dekat sarang, mulut sarang tertutup, tercium bau amis menyengat, biasanya induk jantan berada dekat sarang, jika sarang ditusuk dengan jari telur akan terlihat keluar terapung di permukaan. Sarang yang telah berisikan telur harus segera diangkat dengan perlahan-lahan pada pagi atau sore hari. Telur yang terbuahi berwarna kuning bening dipisahkan dari telur yang rusak atau tidak terbuahi berwarna kuning keputihan atau kuning pucat. Nilai derajat pembuahan telur atau FR (fertilization rate) yang didapatkan adalah 53,54 \%. Menurut BSN (2000b), produksi telur ikan gurame betina adalah $1.500-2.500$ butir/kg bobot induk.

\section{Penetasan Telur dan Pemeliharaan Larva}

Telur gurame ditetaskan di dalam akuarium berukuran $1,5 \mathrm{~m} \times 0,5 \mathrm{~m} \times 0,5 \mathrm{~m}$ di dalam ruangan tertutup (indoor). Penempatan akuarium di dalam ruangan membuat kondisinya terkontrol (Satyani dan Bambang, 2012). Kepadatan telur dalam setiap akuarium kurang lebih 1500 butir. Telur gurame menetas rata-rata setelah 30 jam. Telur yang menetas menghasilkan larva yang masih memiliki kuning telur. Menurut Lucas dkk. (2015), larva yang baru menetas tidak perlu diberi pakan karena masih memiliki cadangan makanan berupa kuning telur. Kuning telur akan habis setelah 10 hari. Kuning telur akan diserap selama beberapa hari sambil menunggu proses penyempurnaan alat pencernaan (Ghofur dkk., 2014). Nilai derajat penetasan telur atau HR (hatching rate) dan tingkat kelangsungan hidup atau SR (survival rate) yang didapatkan secara berturut-turut adalah 87,73 \% dan 86,26 $\%$. Besar kecilnya kelulushidupan dipengaruhi oleh faktor internal yang meliputi jenis kelamin, keturunan, umur, reproduksi, ketahanan terhadap penyakit dan faktor eksternal meliputi kualitas air, padat penebaran, jumlah dan komposisi kelengkapan asam amino dalam pakan (Nugroho dkk., 2015).

Larva segera diberi pakan alami cacing sutera setelah kuning telur habis. Cacing sutera sangat baik bagi pertumbuhan ikan air tawar termasuk 
benih gurame post larva karena kandungan proteinnya tinggi, selain itu umumnya kelas oligochaeta tidak mempunyai kerangka skeleton sehingga mudah dan cepat dicerna dalam usus ikan (Subandiyah dkk., 2003). Cacing sutera mengandung 57 \% protein, 13,30 \% lemak dan 2,04 \% karbohidrat (Lucas dkk., 2015). Frekuensi pemberian pakan alami cacing sutera adalah sekali sehari dengan dosis satu wadah pakan penuh yaitu sekitar 47 gram.

\section{Pendederan}

Pendederan adalah pemeliharaan benih ikan yang bertujuan untuk mendapatkan benih ukuran tertentu. Pendederan dilakukan hanya dua kali. Pendederan I adalah pemeliharaan benih ikan dari ukuran 0,75-1,00 cm menuju ukuran 1,0-2,0 cm (BSN, 2000b). Pendederan I dilakukan di kolam terpal dan kolam fiberglass. Kolam terpal berbentuk persegi panjang berukuran 11,5 $\mathrm{m} \times 7,5 \mathrm{~m} \times 0,7 \mathrm{~m}$ dengan padat tebar benih ikan gurame sekitar 24.000 ekor. Sementara kolam fiber berbentuk persegi panjang berukuran $4 \mathrm{~m} \times 1,2 \mathrm{~m} \times 0,8 \mathrm{~m}$ dengan padat tebar sekitar 4.000 ekor setiap kolam. Benih dalam kolam pendederan I diberi pakan cacing sutera dengan frekuensi dua kali sehari yaitu pagi dan sore secara ad-libitum dengan dosis rata-rata 800 gram untuk kolam terpal dan 100 gram untuk kolam fiber berdasarkan kepadatan benih dalam masing-masing kolam.

Pendederan II adalah pemeliharaan benih dari ukuran 1,0-2,0 cm menuju ukuran 2,0-4,0 cm (BSN, 2000b). Pendederan II dilakukan di kolam beton berbentuk persegi panjang berukuran 19,3 $\mathrm{m} \times 6,3 \mathrm{~m} \times 1 \mathrm{~m}$ dengan padat tebar sekitar 30.000 ekor. Benih dalam kolam pendederan II masih diberi pakan cacing sutera sembari dilatih sedikit demi sedikit untuk pakan pellet dengan frekuensi pemberian pakan adalah dua kali sehari yaitu pagi dan sore secara ad-libitum dengan dosis rata rata satu kilogram pakan cacing sutera.
Pakan yang diberikan untuk benih gurame ditambah ekstrak rempah-rempah yaitu jahe merah dan jahe biasa, kunyit kuning dan putih, temulawak, temulawak hitam dan kencur. Rimpang kunyit mengandung minyak atsiri sebanyak $6 \%$, zat warna kuning yang disebut kurkuminoid sebanyak $5 \%$, protein, fosfor, kalium, besi dan vitamin C. Kunyit mampu memberikan efek terbentuknya sistem imun dalam tubuh sehingga lebih kuat dan tahan terhadap serangan parasit (Ghofur dkk., 2016). Temulawak mengandung kurkuminoid pada rimpang yang bersifat antibacteria sehingga sangat bagus untuk dipakai sebagai anti bakteri pada ikan sehingga ikan tidak rentan terhadap serangan penyakit serta memberikan kontribusi terhadap pertumbuhan benih gurame (Suminto dan Diana, 2015).

\section{Panen}

Pemanenan dilakukan pada pagi atau sore hari karena suhu tidak terlalu panas sehingga ikan akan merasa nyaman dan tidak stress. Benih digrading untuk memisahkan antara benih yang hidup dan mati serta untuk mendapatkan ukuran benih yang seragam (Adida dkk., 2014). Setelah grading, benih dihitung sesuai permintaan pembeli.

\section{Pasca Panen}

Packing dilakukan setelah diperoleh jumlah dan ukuran yang diinginkan. Packing dapat dilakukan dengan dua cara yaitu menggunakan plastik untuk jarak yang agak jauh dan menggunakan jirigen untuk pengangkutan jarak dekat. Benih didistribusikan ke pembudidaya ikan gurame lokal di sekitar Balai Benih Ikan Ngoro. Benih yang dijual di Balai Benih Ikan Ngoro hanya benih yang berukuran silet dan korek atau 2,5 cm - $3 \mathrm{~cm}$ ke atas dengan harga benih berukuran silet adalah Rp 900, silet $-1 \mathrm{Rp} 800$, silet $+1 \mathrm{Rp} 1.000$, korek Rp 1.250, korek +1 Rp 1.350 dan korek +2 Rp 1.500 . 


\section{Hama dan Penyakit dalam Pembenihan Ikan Gurame (Osphronemus gouramy)}

Hama adalah hewan berukuran lebih besar dan mampu menimbulkan gangguan pada ikan (Kristina dan Sulantiwi, 2015). Beberapa jenis hama yang sering ditemukan menyerang ikan gurame di Balai Benih Ikan Ngoro adalah uncrit atau larva cybister, ular dan biawak.

Penyakit yang menyerang ikan gurame di Balai Benih Ikan Ngoro berasal dari golongan jamur dan bakteri. Jamur yang biasanya menyerang telur ikan gurame adalah Saprolegnia sp. Jamur akan menyerang telur ikan pada kondisi lingkungan yang tidak baik, telur ikan yang terserang ditandai dengan tumbuhnya benang-benang halus. Bila serangannya tidak dihentikan jamur akan menyebar pada telur yang lain dan telur akan mati (Ghofur dkk., 2014). Jamur yang biasanya menyerang larva gurame adalah Aphanomyces sp. Jamur ini menyebabkan tubuh larva gurame berwarna lebih hitam atau gelap dan terdapat seperti kapas putih pada bagian tubuh dan ekor ikan, sedangkan tingkah lakunya yaitu ikan terapung di bawah permukaan air dan sesekali ikan berenang hiperaktif (Efrianti, 2013).

Bakteri yang menyerang ikan gurame adalah bakteri Pseudomonas sp., Aeromonas sp., dan Bacillus sp. yang menyebabkan cacar ikan. Selain itu penyakit bakterial lain yang menyerang ikan gurame adalah Mycobacteriosis yang disebabkan oleh bakteri Mycobacterium sp. Infeksi bakteri ini menyebabkan mata menonjol keluar (exopthalmia) dan benjolan pada tubuh (Rahman, 2008).

Pencegahan dan pengobatan penyakit di Balai Benih Ikan Ngoro dilakukan menggunakan obat dengan merk dagang cat fish keep dan larutan garam dengan dosis 500-1000 gram/1000 liter tergantung ukuran benih, tingkat kepadatan serta tingkat keparahan penyakit. Menurut Rosidah dan Wila (2012) upaya penanggulangan terhadap serangan penyakit dapat dilakukan melalui tindakan pencegahan dengan cara mengontrol kualitas air agar sesuai, pemberian pakan yang sesuai baik kualitas maupun kuantitasnya, sedangkan pengobatan dapat dilakukan dengan menggunakan bahan kimia atau antibiotik.

\section{Hambatan dalam Pembenihan Ikan Gurame (Osphronemus gouramy)}

Hambatan dalam pembenihan ikan gurame meliputi faktor internal yang berasal dari biologis ikan gurame sendiri yaitu pertumbuhannya lambat sehingga proses budidaya dan pembenihan memerlukan waktu yang lebih lama. Hambatan dalam pembenihan ikan gurame yang berasal dari faktor eksternal adalah faktor lingkungan yang menyebabkan ketersediaan pasokan benih menurun pada waktu tertentu karena produksi telur yang kurang maksimal, kualitas air dan penyakit yang berakibat pada tingginya mortalitas larva dan benih ikan gurame.

\section{KESIMPULAN DAN SARAN Kesimpulan}

Kesimpulan dari hasil Praktek Kerja Lapang tentang Teknik Pembenihan Ikan Gurame (Osphronemus gouramy) di Balai Benih Ikan Ngoro, Jombang yaitu teknik pembenihan ikan gurame (Osphronemus gouramy) meliputi persiapan kolam pemijahan, seleksi induk, pemijahan, pemanenan telur, penetasan telur dan pemeliharaan larva, pendederan, penanganan hama dan penyakit, panen dan pasca panen. Hambatan yang terdapat dalam teknik pembenihan ikan gurame (Osphronemus gouramy) adalah faktor internal yaitu biologis ikan dan faktor eksternal yaitu faktor lingkungan, kualitas air dan penyakit.

\section{Saran}

Saran yang dapat diberikan untuk meningkatkan produksi benih ikan gurame adalah perlu dilakukan kontrol kualitas air dan pembangunan laboratorium untuk mempercepat penanganan apabila ikan 
gurame mengalami serangan wabah penyakit.

\section{DAFTAR PUSTAKA}

Adida., K. Nirmala dan S. Harijati. 2014. Efisiensi Pemasaran Benih Ikan Gurami (Osphronemus gouramy) Ukuran 'Nguku' ditinjau dari Keragaman Pasar di Kelurahan Duren Mekar dan Duren Seribu, Depok Jawa Barat. Jurnal Manajemen Perikanan dan Kelautan, 1 (1) : 1-9.

Arfah, H., L. Maftucha dan O. Carman. 2006. Pemijahan Secara Buatan Pada Ikan Gurame Osphronemus gouramy Lac. By dengan Penyuntikan Ovaprim. Jurnal Akuakultur Indonesia, 5 (2) : 103112.

Badan Standar Nasional. 2000b. Produksi Benih Ikan Gurame (Osphronemus gouramy, Lac) Kelas Benih Sebar. Standar Nasional Indonesia. hal. 25.

Caniago, A., Y. Basri dan Azrita. 2014. Pengaruh Perbandingan Induk Jantan dan Betina dalam Pemijahan Ikan Sepat Mutiara (Tricogaster leeri Blkr) Terhadap Fekunditas dan Daya Tetas Telur. Prosiding Hasil Penelitian Mahasiswa FPIK, 5 (1): 12 hal.

Efrianti, R. 2013. Pemberian Ekstrak Batang Pisang Ambon (Musa paradisiaca) Pada Media Pemeliharaan Untuk Meningkatkan Kelangsungan Hidup Larva Ikan Gurame (Osphronemus gouramy). Skripsi. Budidaya Perairan. Fakultas Perikanan dan Ilmu Kelautan. Institut Pertanian Bogor. Bogor. 26 hal.

Fais, M. 2008. Analisis Strategi Bisnis Usaha Pembenihan Ikan Gurame Pada Kelompok UPR Gurame Mitra Karya Mandiri, Desa Barengkok, Kecamatan Leuwiliang, Kabupaten Bogor
Provinsi Jawa Barat. Skripsi. hal. 72.

Ghofur, M., M. Sugihartono dan R. Thomas. 2014. Efektifitas Pemberian Ekstrak Daun Sirih (Piper betle. L) Terhadap Penetasan Telur Ikan Gurami (Osphronemus gouramy Lac.). Jurnal Ilmiah Universitas Batanghari Jambi, 14 (1) : 37-44.

Ghofur, M., M. Sugihartono dan J. Arfah. 2016. Uji Efektifitas Ekstrak Kunyit (Curcuma domestica) Terhadap Daya Tetas Telur Ikan Gurami (Osphronemus gouramy Lac.). Jurnal Ilmiah Universitas Batanghari Jambi, 16 (1) : 68-76.

Gunadi, B., Lamanto dan R. Febrianti. 2010. Pengaruh Pemberian Pakan Tambahan dengan Kadar Protein yang Berbeda Terhadap Jumlah dan Fertilitas Telur Induk Gurame. Prosiding Forum Inovasi Teknologi Akuakultur. Loka Riset Pemuliaan dan Teknologi Budidaya Perikanan Air Tawar. 6 hal.

Irawan, P. B., Zulfanita dan I. A. Wicaksono. 2012. Analisis Usaha Pembenihan Gurami (Osphronemus gouramy Lacepede) di Desa Kaliurip Kecamatan Bener Kabupaten Purworejo. Surya Agritama, 1 (2) : 24-33.

Khairuman dan K. Amri. 2005. Pembenihan dan Pembesaran Gurami Secara Intensif. PT. AgroMedia Pustaka. Depok. hal. 11.

Kristina, M. dan Sulantiwi. 2015. Sistem Pendukung Keputusan Menentukan Kualitas Bibit Ikan Gurame Di Pekon Sukosari Menggunakan Aplikasi Visual Basic 6.0. Jurnal Technology Acceptance Model 4 : 26-33.

Lucas, W. G. F., O. J. Kalesaran dan C. Lumenta. 2015. Pertumbuhan dan Kelangsungan Hidup Larva Ikan Gurami (Osphronemus gouramy) dengan Pemberian Beberapa Jenis 
Pakan. Jurnal Budidaya Perairan, 3 (2) : 19-28.

Nugroho, M. H. 2008. Analisis Pendapatan dan Faktor-Faktor yang Mempengaruhi Hasil Produksi Pembenihan Ikan Gurami Petani Bersertifikat SNI. Skripsi. Eksistensi Manajemen Agribisnis. Fakultas Pertanian. Institut Pertanian Bogor. Bogor. 90 hal.

Nugroho, I. I., Subandiyono dan V. E. Herawati. $2015 . \quad$ Tingkat Pemanfaatan Artemia sp. Beku, Artemia sp. Awetan dan Cacing Sutera Untuk Pertumbuhan dan Kelangsungan Hidup Larva Ikan Gurami (Osphronemus gouramy Lac.). Journal of Aquaculture Management and Technology, 4 (2) : 117-124.

Rahman, M. F. 2008. Potensi Antibakteri Ekstrak Daun Pepaya Pada Ikan Gurami yang Diinfeksi Bakteri Aeromonas hydrophila. Skripsi. Fakultas Kedokteran Hewan. Institut Pertanian Bogor. Bogor. 62 hal.

Rosidah dan W. M. Afizia. 2012. Potensi Ekstrak Daun Jambu Biji Sebagai Antibakterial Untuk Menanggulangi Serangan Bakteri Aeromonas hydrophila Pada Ikan Gurame (Osphronemus gouramy lacepede). Jurnal Akuatika, 3 (1): 19-27.

Satyani, D. dan B. Priono. 2012. Penggunaan Berbagai Wadah Untuk Pembudidayaan Ikan Hias Air Tawar. Media Akuakultur, 7 (1) : 14-19.

Subandiyah, S., D. Satyani dan Aliyah. 2003. Pengaruh Subtitusi Pakan Alami (Tubifex) dan Buatan Terhadap Pertumbuhan Ikan Tilan Lurik Merah (Mastacembelus erythrotaenia Bleeker, 1850). Jurnal Iktiologi Indonesia, 3 (2) : 67-72.

Sulhi, M. 2010. Produksi Benih Gurame Dilahan Sempit. Seminar Nasional
Pangan Sedunia XXVII. Balai Riset Perikanan Budidaya Air Tawar. Bogor. 6 hal.

Sulhi, M., R. Samsudin., J. Subagja dan Hendra. 2012. Peningkatan Kualitas dan Kuantitas Produksi Benih Gurame Melalui Penggunaan Ekstrak Daun Sente (Alocasia macrorrhiza) dalam Pakan Induk. Prosiding Indoaqua-Forum Inovasi Teknologi Akuakultur. Bogor. 6 hal.

Suminto dan D. Chilmawati. Pengaruh Probiotik Komersial Pada Pakan Buatan Terhadap Pertumbuhan, Efisiensi Pemanfaatan Pakan, dan Kelulushidupan Benih Ikan Gurami (Osphronemus gouramy) $\mathrm{D}_{35}-\mathrm{D}_{37}$. 2015. Jurnal Saintek Perikanan, 11 (1) : 11-16. 